\title{
Sediment Quality-Assurance Plan for the New Mexico Water Science Center of the U.S. Geological Survey
}

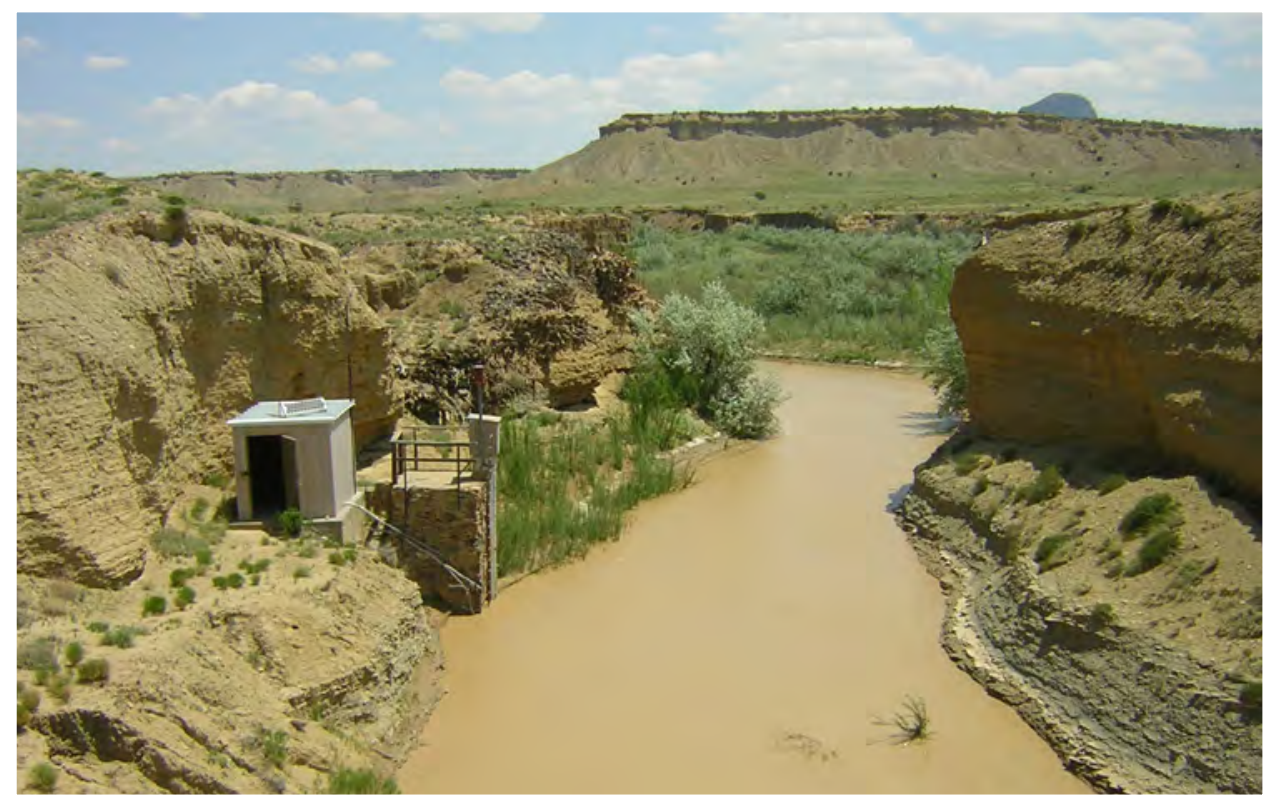

Open-File Report 2007-1265 


\section{Sediment Quality-Assurance Plan for the New Mexico Water Science Center of the U.S. Geological Survey}

By J. Stiles and D. Michael Roark

Open-File Report 2007-1265 


\section{U.S. Department of the Interior DIRK KEMPTHORNE, Secretary}

\section{U.S. Geological Survey Mark D. Myers, Director}

\section{U.S. Geological Survey, Reston, Virginia 2007}

For product and ordering information:

World Wide Web: http://www.usgs.gov/pubprod

Telephone: 1-888-ASK-USGS

For more information on the USGS - the Federal source for science about the Earth, its natural and living resources, natural hazards, and the environment:

World Wide Web: http://www.usgs.gov

Telephone: 1-888-ASK-USGS

Suggested citation:

Stiles, J., and Roark, D.M., 2007, Sediment quality-assurance plan for the New Mexico Water Science Center of the U.S. Geological Survey: U.S. Geological Survey Open-File Report 2007-1265, 19 p.

Any use of trade, product, or firm names is for descriptive purposes only and does not imply endorsement by the U.S. Government.

Although this report is in the public domain, permission must be secured from the individual copyright owners to reproduce any copyrighted material contained within this report. 


\section{Contents}

Conversion Factors ....................................................................................................................

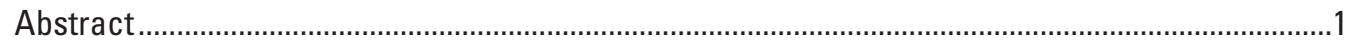

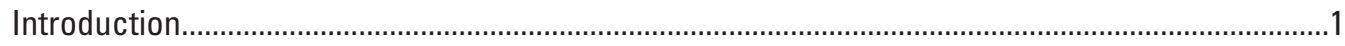

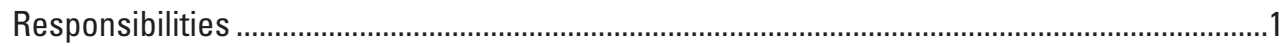

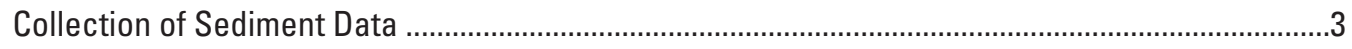

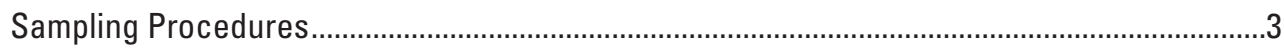

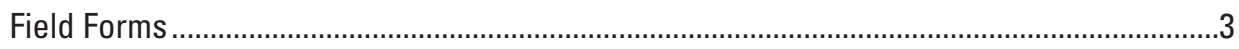

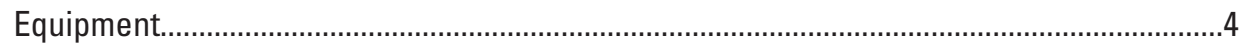

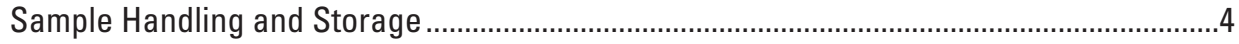

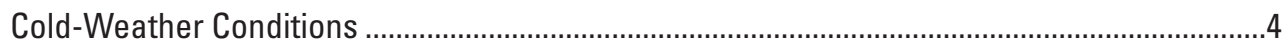

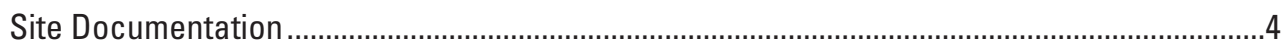

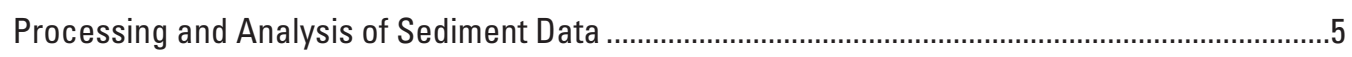

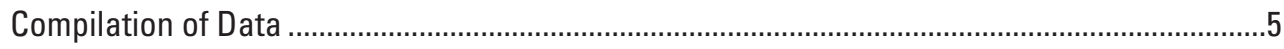

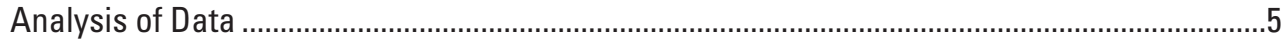

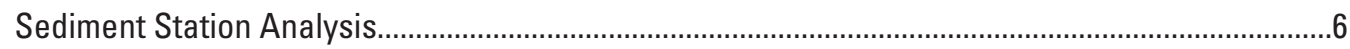

Quality-Assurance Review of Sediment Records ..................................................................

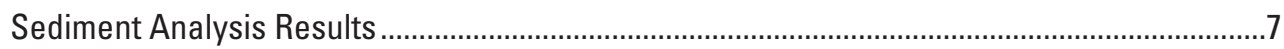

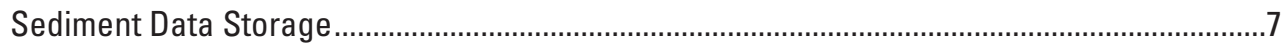

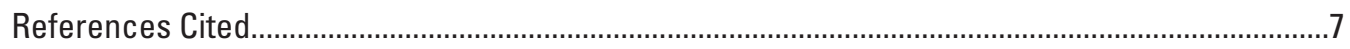

Appendix 


\section{Conversion Factors}

\begin{tabular}{lcl}
\hline \multicolumn{1}{c}{ Multiply } & \multicolumn{1}{c}{ By } & \multicolumn{1}{c}{ To obtain } \\
\hline inch (in.) & 2.54 & centimeter $(\mathrm{cm})$ \\
inch (in.) & 25.4 & millimeter $(\mathrm{mm})$ \\
foot (ft) & 0.3048 & meter $(\mathrm{m})$ \\
mile (mi) & 1.609 & kilometer $(\mathrm{km})$ \\
\hline \multicolumn{1}{c}{ Area } & \\
\hline acre & 4,047 & square meter $\left(\mathrm{m}^{2}\right)$ \\
acre & 0.4047 & hectare $($ ha) \\
acre & 0.4047 & square hectometer $\left(\mathrm{hm}^{2}\right)$ \\
acre & 0.004047 & square kilometer $\left(\mathrm{km}^{2}\right)$ \\
square mile $\left(\mathrm{mi}^{2}\right)$ & 259.0 & hectare $($ ha) \\
square mile $\left(\mathrm{mi}^{2}\right)$ & 2.590 & square kilometer $\left(\mathrm{km}^{2}\right)$ \\
\hline & \multicolumn{1}{c}{ Flow rate } & \\
\hline cubic foot per second $\left(\mathrm{ft}^{3} / \mathrm{s}\right)$ & 0.02832 & cubic meter per second $\left(\mathrm{m}^{3} / \mathrm{s}\right)$ \\
\hline
\end{tabular}

Temperature in degrees Celsius $\left({ }^{\circ} \mathrm{C}\right)$ may be converted to degrees Fahrenheit $\left({ }^{\circ} \mathrm{F}\right)$ as follows:

$$
{ }^{\circ} \mathrm{F}=\left(1.8 \times{ }^{\circ} \mathrm{C}\right)+32
$$

Vertical coordinate information is referenced to the insert datum name (and abbreviation) here for instance, "North American Vertical Datum of 1988 (NAVD 88)."

Horizontal coordinate information is referenced to the insert datum name (and abbreviation) here for instance, "North American Datum of 1983 (NAD 83)." 


\title{
Sediment Quality-Assurance Plan for the New Mexico Water Science Center of the U.S. Geological Survey
}

\author{
By J. Stiles and D. Michael Roark
}

\begin{abstract}
This report describes a sediment quality-assurance plan for the U.S. Geological Survey, New Mexico Water Science Center (WSC), to assure that standard procedures for collecting, storing, shipping, and processing are followed. The plan also serves as a guide for all WSC personnel involved in sediment activities.
\end{abstract}

\section{Introduction}

The U.S. Geological Survey (USGS) was established by an act of Congress on March 3, 1879, to provide a permanent Federal agency to perform the systematic and scientific "classification of the public lands, and examination of the geologic structure, mineral resources, and products of the national domain." Sediment activities in the New Mexico Water Science Center (WSC) are part of the overall mission of the Water Resources Division (WRD) to assess the Nation's water resources. Sediment information is used at the Federal, State, and local levels for resource planning and management.

This report describes the field standards, policies, and procedures used by the USGS New Mexico WSC, for activities related to the collection, processing, storage, analysis, and publication of sediment data and identify responsibilities for ensuring that stated policies and procedures are carried out. In addition, issues related to the management of employee safety and training are presented. Although procedures and products of interpretive projects are subject to the criteria presented in this report, specific interpretive projects are required to have a separate and complete Quality Assurance (QA) plan. This QA plan is reviewed and revised at least once every 3 years so that responsibilities and methodologies are kept current and ongoing procedural improvements can be effectively documented.

\section{Responsibilities}

Quality assurance is an active process. High-quality standards for surface-water data are achieved and maintained by specific actions carried out by specific people; errors and deficiencies can result when individuals fail to carry out their responsibilities. Clear and specific statements of responsibilities promote an understanding of each person's duties in the overall process of assuring high-quality sediment data. The following is a list of general responsibilities of WSC personnel involved in the project management, collection, processing, storage, analysis, or publication of sediment data.

\section{The Water Science Center Director is responsible for the following:}

- Managing and directing the WSC program, including all sediment activities.

- Ensuring that sediment activities in the WSC meet the needs of the Federal Government, the New Mexico WSC, State and local agencies, other cooperating agencies, and the general public.

- Ensuring that all aspects of this QA plan are understood and followed by WSC personnel by the WSC Director's direct involvement or by clearly stated delegation of this responsibility to other personnel in the WSC.

- Providing final resolution of any conflicts or disputes related to sediment activities within the WSC.

- Keeping subordinates briefed on procedural and technical communications from regional offices and headquarters.

- Performing quarterly technical reviews of all sediment programs.

- Ensuring that all publications and other technical communications released by the WSC are accurate and in accord with USGS policy. 


\section{The Associate Water Science Center Director is responsible for the following:}

- Making binding commitments for the WSC and implementing policies established by the WSC Director.

- Directing operations in the absence of the WSC Director.

- Advising the Regional and Chief Hydrologists on all phases of water resources in the State of New Mexico.

- Ensuring that all sediment data-collection activities completed by the Investigations Section meet the standards established by the USGS and the New Mexico WSC.

\section{The Assistant Water Science Center Director (Data Chief) is responsible for the following:}

- Assisting the WSC Director in the scientific, technical, and administrative direction of all sediment-resources programs of the WSC.

- Maintaining a close working relationship with Field Office Chiefs.

- Assuring data collection and processing are in accordance with WSC, WRD, and USGS policies.

- Meeting with cooperators to ensure that the data program is viable and fulfills the mission of the USGS.

\section{The Surface Water Specialist is responsible for the following:}

- Technically reviewing project proposals that contain sediment data collection or interpretation.

- Reviewing sediment data-collection methods of the Data and Investigation Sections, and reviewing approximately 10 percent of computed sediment records each year.

- Providing technical training as needed to personnel of the Data and Investigations Sections.

- Ensuring personnel are trained in correct procedures to collect sediment samples.

- Ensuring correct procedures are being used by performing a site trip with personnel collecting sediment samples or by discussing procedures and problems at meetings held once or twice each year. Documentation on procedures and problems will be distributed to appropriate personnel.

- Providing answers to questions from WSC personnel concerning sediment-sampling techniques.

\section{The Field Office Chief is responsible for the following:}

- Designing data-collection activities.

- Assuring the accuracy of gaging-station records.

- Ensuring personnel use correct procedures to collect sediment samples.

- Providing leadership for staff members.

- Maintaining expertise in all phases of data collection, compilation, and computation.

- Providing on-the-job training (OJT) and formal training for subordinates.

\section{The Sediment Project Chief is responsible for the following:}

- Assisting the Field Office Chief in the design of datacollection activities.

- Assisting the Field Office Chief in providing OJT in records computation, field work, and surveying.

- Ensuring that appropriate equipment is used at all sampling sites.

- Reviewing the field and records work of field personnel and ensuring accuracy of data.

- Transferring sample data from Sediment Laboratory Environmental Data System (SLEDS) into Water Quality System (QWDATA) database.

- Reviewing all aspects of sediment data publications, including the annual data report and National Water Information System (NWIS) web.

\section{The Field Hydrologic Technician or Hydrologist is responsible for the following:}

- Scheduling sediment-collection activities at specific sites.

- Ensuring that appropriate equipment is used at all sampling sites.

- Collecting cross-sectional samples using the equal width increment (EWI) method.

- Installing, serving, and maintaining automatic pump samplers.

- Logging sample data into QWDATA.

- Computing sediment records and writing station descriptions and analyses.

- Entering daily mean concentrations and loads into NWIS and preparing the manuscript for the annual data report. 


\section{The Safety Officer is responsible for the following:}

- Disseminating safety information to WSC personnel.

- Making periodic inspections of all working areas in the WSC and field offices.

- Maintaining a WSC library of safety information.

- Organizing safety training classes and overseeing the WSC Safety Committee.

\section{Collection of Sediment Data}

Sediment activities in the New Mexico WSC include the collection, processing, analysis, and publication of sediment data. The New Mexico WSC operates in adherence to policies related to sediment set forth by the Office of Surface Water (OSW).

Responsibility for the sediment discipline was transferred from the Office of Water Quality (OWQ) to the OSW in 1985 (Office of Surface Water memorandum 92.08). The policies and procedures related to sediment followed by the New Mexico WSC are described in selected WRD publications and in memorandums issued by OSW, OWQ, and the WRD. Techniques adopted by the USGS and followed by this WSC are presented in Knott and others (1992). The New Mexico WSC also follows procedures presented in three publications from the series "Techniques of Water-Resources Investigations of the U.S. Geological Survey" (TWRI): 1969),

Book 3, Chapter C1--"Fluvial Sediment Concepts" (Guy,

Book 3, Chapter C2--'Field Methods for Measurement of Fluvial Sediment" (Edwards, and Glysson, 1999).

Book 3, Chapter C3--"Computation of Fluvial-Sediment Discharge" (Porterfield, 1972).

\section{Sampling Procedures}

The New Mexico WSC has a unique sediment program wherein several sites are set up to collect suspended-sediment samples every day by using an automatic pump sampler. For selection, installation, and use of the automatic samplers, the WSC follows the criteria described in Edwards and Glysson (1999, p. 32).

The automatic samplers are serviced approximately every 24 days, at which time three manual pump samples are collected in addition to two cross-section samples by use of the equal width increment (EWI) method. These two crosssection samples are used to determine a reference coefficient with the point samples collected from the automatic sampler. The cross-section samples are collected by using OSW approved samplers. The samples should be taken as close as possible to the sampler intake to avoid having the point sample and the cross-section samples collected under different hydrologic conditions.

At various sites a monthly total-load sediment sample is collected. This sample consists of both a suspended-sediment size sample and a bed-material sample. Both of these samples are collected by using the EWI sampling method and analyzed for particle-size distribution. Policy for the collection and publication of bedload data is provided in OSW memorandum 90.08 .

Turbidity samples are also collected monthly at various sites. Collection consists of a composite cross-section sample that is placed in a churn. The composite sample is churned at a uniform rate by raising and lowering the disk inside the churn splitter with smooth, even strokes. While churning, the disk should touch the bottom and should not break the surface of the water. The churning rate should be about 9-inches per second (U.S. Geological Survey, National Field Manual for the Collection of Water-Quality Data, Book 9). The sample is then poured through the churn spigot into a $500 \mathrm{~mL}$ bottle that must be kept cool. An additional cross-section sample must be collected for concentration analysis.

\section{Field Forms}

The New Mexico WSC has created two field forms that technician are required to fill out each time a site is visited for the purpose of sediment sampling; one is the Automatic Sampler Field Form and the other is Sediment Data Collection Field Notes. The forms are available on the New Mexico WSC data server. An example of each field form is in the Appendix at the end of this report. The technician completes each field form in its entirety before leaving the site. Original observations written on the field forms are not to be erased; data are corrected by crossing out the original observations and writing the correct information near the original value. The goal of placing information on the field form sheet is to describe the equipment and methods used during the site visit as well as to describe relevant conditions or changes (Office of Surface Water memorandum 91.15).

For the Automatic Sampler Field Form, information on the field form includes, at minimum, site identification, and field personnel name, date, and time. If an automatic pump sampler is installed, notes should include status of pump sampler and whether on standby or in an active program. Notes should include number, date, and time of each sample collected by the machine. Notes should also indicate if clean sample containers were replaced in the machine as well as any problems with the pump sampler or sampler intake line.

The Sediment Data Collection Field Notes includes, at minimum, site identification; field personnel name, date, and time; location of the cross-section sample in relation to the pump sampler; sampling equipment; and sampling method. The weather conditions and sampling location should also be indicated. 
Upon completion of each field trip, the field forms are placed in the site-record folder. Field notes are checked by the Sediment Project Chief after each field trip.

\section{Equipment}

Care and maintenance of the sediment data-collection equipment are the responsibility of field personnel who use the specific equipment. Parts replacement and repair of damaged equipment are accomplished by the personnel who use the specific equipment. Replacement nozzles and seals are obtained from the Sediment Project Chief, and damaged equipment is turned over to the Sediment Project Chief for repair. It is the responsibility of the Sediment Project Chief and field personnel to ensure that appropriate equipment is used at all sampling sites. Sampling equipment is selected based on the constituents that are being investigated, the type of analyses that need to be performed, and site conditions, including velocity and maximum depth of water. The WSC follows equipment-design criteria and guidelines referenced in Office of Surface Water memorandum 93.01.

\section{Sample Handling and Storage}

The quality of sediment data provided by a sediment laboratory is affected by the quality of the samples received from the field. The New Mexico WSC personnel are required to prepare sample labels, analysis instructions, and sample documentation according to guidelines presented in Knott and others (1992).

Prior to being used on field trips, sample containers are stored inside boxes in the sediment laboratory. During field trips, sample containers are stored in plastic crates or sample holders, and bottles are sealed with plastic caps. After a sample container has been filled with a sediment sample, the container is stored for the remainder of the field trip in a plastic crate or sampler holder and is protected from freezing temperatures. After the field trip, the sample containers are given to the New Mexico WSC Laboratory within 1 week of collection for further handling. All sample containers given to the laboratory must contain a field-form sheet. After the laboratory receives the sample containers laboratory personnel decide where the sample containers go next. All concentration and sand-fine split samples are processed in the New Mexico WSC Laboratory. All full size and bed-material samples are shipped to the Iowa WSC Laboratory. The samples that are processed in the New Mexico WSC Laboratory are processed within 2 weeks; if it will take longer than 2 weeks, the sample containers are stored in a cool dark place to prevent algae growth and are then processed as soon as possible.

\section{Cold-Weather Conditions}

When conditions are cold enough, it may be necessary to move the sampling equipment quickly when outside of the water to avoid ice build up that could clog the nozzle. Care also must be taken to ensure the samples do not freeze while being transported to the laboratory. When unloading samples from the pump sampler, technicians should note whether or not the sample bottles are frozen; the sample intake line should also be checked for signs of freezing.

\section{Site Documentation}

A station description is prepared in the Station Information Management System (SIMS) for each new sediment-sampling site. At sampling sites where streamflowgaging activities occur, the description of sediment activities is included in the gaging-station description. Elements found in the gaging-station description are as follows:

- location: latitude, longitude, county, location in reference to stream

- road log: detailed directions to the site

- drainage area

- establishment and history

- gage: equipment installed

- control

- discharge measurements- applicable types, wading, bridge or cable way

- floods

- point of zero flow

- winter flow: if operational during winter months

- regulations and diversions

- accuracy of records

- cooperation

- map: name of the 7-1/2 minute topographic map

- reference marks

- land ownership.

At sites where sediment samples are collected, the station descriptions are structured similarly to those for streamflowgaging stations, with the following additional elements pertaining to the sediment portion:

- establishment

- cooperation

- equipment

- sampling program. 
At sampling sites where gage houses have been installed, station descriptions are kept in the gage house to provide field personnel with information pertinent to sediment-sampling procedures for that particular site. Station descriptions are also included in the field folder and are maintained in the office files. Each description includes specific information explaining where the site samples are to be collected and what method is to be used.

The responsibility of ensuring that field copies of station descriptions located at gage houses are kept current is held by field personnel assigned to regularly run specific field trips. Station descriptions are kept current by annual review and updating. When a deficiency is identified during the review of station descriptions, the deficiency is corrected by the field personnel. Field personnel are responsible for ensuring the corrected deficiencies have been documented in the sedimentstation descriptions.

At sampling sites with a gage house, a log of sampling activities is kept. The log will contain information about sample collection, servicing of automatic pump samplers, equipment problems, and flow conditions for each visit to the site.

\section{Processing and Analysis of Sediment Data}

Sediment and associated streamflow data are compiled to produce sediment records for specific sites. Data processing of periodic measurements consists of four steps: tabulation, evaluation, editing, and verification (Office of Surface Water memorandum 91.15). The WSC follows the considerations and guidelines presented in Porterfield (1972), Guy (1969), and Office of Surface Water memorandum 91.15 in carrying out these four steps.

The Sediment Project Chief is responsible for ensuring that appropriate procedures are correctly applied in processing sediment data. During the time the sediment data are being processed for the year, and after the record has been completed, field notes and work sheets for each site are maintained in the New Mexico WSC sediment laboratory.

\section{Compilation of Data}

The New Mexico WSC laboratory is equipped to analyze sediment samples for concentration and percent as of sand/silt breaks only. Analyses are performed on samples submitted by the New Mexico WSC sediment data-collection program, other New Mexico WSC projects, and other Federal agencies. The laboratory receives a triennial onsite review by appropriate technical or management personnel from the OSW. These reviews examine all aspects of laboratory operations (Knott and others, 1993, p. 14).
A copy of the New Mexico sediment laboratory QA plan is kept in the WSC sediment laboratory. The plan describes the equipment, specifications, calibration and maintenance, and the protocol for methods used in the analyses of fluvial sediment for concentration or sand/silt breaks.

Primary responsibility for ensuring that appropriate equipment and procedures are used in this laboratory is held by the Laboratory Chief. The laboratory is operated according to procedures described in Knott and others (1992) and Guy (1969) for calibration and maintenance of equipment, analytical procedures, and documentation.

The New Mexico WSC also adheres to policies described in memorandums issued by OSW, OWQ, and WRD. Policies on accepted methods of sediment-size determinations are outlined in Office of Surface Water memorandum 93.11.

\section{Analysis of Data}

Sediment data and records are compiled by using procedures described in TWRI Computation of Fluvial Sediment Discharge (Porterfield, 1972). Computations are made by using the Graphical Constituent Loading Analysis System (GCLAS) (Koltun and others, 2006).

Several preparatory steps must take place before opening GCLAS. The first step is to tabulate and evaluate sediment samples:

- Request retrieval of the Sediment Laboratory Environmental Data System (SLEDS) program's detail summary report from sediment laboratory personnel.

- Account for all samples; whether they are an automatic pump sample, a cross section sample, or a laboratory blank sample. (Laboratory blank samples consist of the deionized water the laboratory uses to process samples.)

- Report any laboratory data-entry errors detected to the Sediment Project Chief.

The second step is to retrieve data from SLEDS in a format for GCLAS use:

- Request retrieval of a BCARD, described in Koltun and others (2006), and file of lab concentration data from SLEDS.

- Edit the BCARD file by removing any blank samples and inserting indicators for each automatic sample and each cross-section. The automatic sampler samples are identifies with a "p" and the cross-section samples are identified with an "i."

The third step is to create a BCARD format of discharge unit values by using U.S. Geological Survey Automated Data Processing System (ADAPS):

- Create a BCARD file of unit values by using ADAPS (OUTWAT). 
- Edit the BCARD file by fixing estimated days with the correct values. The daily estimate will be entered as a series of unit values for the whole day.

The concentration and discharge BCARD files must then be imported into GCLAS, and the next step would be to compute the daily values in GCLAS:

- Identify in GCLAS any samples that are not going to be used to compute record.

- Set the default representation of estimated values to either "point" or "single section" depending on the type of samples collected. Pump samples should be set to "point."

- Determine and enter estimated sediment concentration values for use in daily computations by using the transport relation window or other tool.

- Compute, analyze, and apply box coefficients to sediment data.

- Compute daily mean values for sediment concentration and load in GCLAS.

- Export daily mean concentration and daily mean sediment discharge files for input into ADAPS.

- After the record is computed in GCLAS the generated daily value BCARD files for concentration and sediment discharge must be loaded into ADAPS.

- All electronic files used in the computation of the sediment record including the BCARD input files, GCLAS files, ADAPS input files, and the station analysis should be placed in the appropriate folder for the year and the station in the sediment records folder on the WSC data documents file server.

- Once the daily value data are loaded into ADAPS, the data should be reviewed for completeness and then set to approve status, using the ADAPS data aging.

- The manuscript for the annual data report must be completed in SIMS.

The sediment-station analysis should be started at the beginning of the computation processes and added to during the whole process of computing and analyzing the sediment record.

The suspended sediment samples and the bed-material samples must be logged into QWDATA. The steps for this are as follows:

- from Unix enter- qwdata

- choose option 1 (log in)

- fill out sheet: mandatory fields are, station number, begin and end date, begin time and medium code

- first question: do you want to add parameters? $=\mathrm{Y}$
- second question: do you want to enter data for this record $?=\mathrm{Y}$

- third question: do you want to enter field or lab data? $=\mathrm{F}$

- fourth question: field form? = 14 (a special form has been created)

- fill out sheet

- obtain record number and record.

\section{Sediment Station Analysis}

A sediment-station analysis is written for each sediment station operated by the New Mexico WSC each water year. The sediment station analysis is a summary of the sediment activities at the station for a given year. The analysis describes the coverage of sampling, the types of samples and sampling, changes that might affect sediment transport or the record, and the methods and reasoning used to compute the record. Information included in the sediment-station analysis is presented in a thorough manner so that the checker and the reviewer can determine from the analysis the adequacy of the activities in defining the record and in accomplishing the objectives defined for the station (Office of Surface Water memorandum 91.15).

Elements included in each sediment-station analysis are as follows:

- sampling program: establishment and history

- equipment

- sediment samples: number of each type of samples collected

- water discharge record

- sediment load computations

- analysis of daily point samples; if a sample was not used then an explanation is needed

- analysis of cross-section samples; if a sample was not used then an explanation is needed

- cross-section coefficients

- an explanation of how well the sample cross-sections relate to pump samples

- estimated concentration and load

- remarks.

An example of a station analysis is in the Appendix at the end of this report. 
A copy of the station analyses is filed with the current year sediment-sample record. The Sediment Project Chief is responsible for ensuring the accuracy of the station analysis at each daily sampling site.

\section{Quality-Assurance Review of Sediment Records}

All sediment records computed by the New Mexico WSC will have at least a two-level review before they are approved for publication. After the computation of the sediment record is completed, personnel will set the record to "worked" in the Records Management System (RMS). Personnel familiar with sediment-record computation will check electronic data files and GCLAS to insure that the computations and analysis of the record are complete and are hydrologically correct. After the checker has set the record as "checked" in RMS, the final review will be completed by personnel completely familiar with sediment-data collection and computation procedures. After the final review, the record will be set as reviewed in RMS, and the daily values in ADAPS will be set as approved by the final reviewer.

\section{Sediment Analysis Results}

The end product of sediment computations and analyses are daily mean sediment concentration and daily mean load that are published in the New Mexico annual data report. The Sediment Project Chief is responsible for ensuring the quality of these data. The Water Resources Division Data Reports Preparation Guide (Novak, 1985) is used for publication guidelines.

\section{Sediment Data Storage}

All sediment samples analyzed by the New Mexico Sediment Laboratory are stored in the New Mexico SLEDS system. In addition cross-sectional samples and bed-material samples are stored in QWDATA. Field sheets, laboratory sheets, SLEDS reports, and notes from the analysis of sediment records are stored in water-year folders and maintained in the New Mexico Sediment Laboratory.

All electronic files produced by the analysis of sediment records are stored on the New Mexico data file server, Data Documents on 'Filer1'/Sediment/Sediment Records/Station Number/WY. After the records have been completed and approved, the electronic files are locked. The Sediment Project Chief will be responsible for putting electronic files onto a CD or other storage media, along with the version of GCLAS and JAVA used to compute the record.

\section{References Cited}

Edwards, T. K., and Glysson, G. D., 1999, Field methods for measurement of fluvial sediment: U.S. Geological Survey Techniques of Water-Resources Investigations, book 3, chap. C2.

Guy, H.P., 1969, Laboratory theory and methods for sediment analysis: U.S. Geological Survey Techniques of WaterResources Investigations, book 5, chap. C1, online at http://pubs.er.usgs.gov/pubs/twri/twri5cl , accessed June $13,2005$.

Guy, H.P., 1970, Fluvial sediment concepts: U.S. Geological Survey Techniques of Water-Resources Investigations, book 3, chap. C1.

Koltun and others, 2006, U.S. Geological Survey User's manual for the Graphical Constituent Loading Analysis System (GLCAS), Book 4, Chapter C1.

Knott, J.M., Glysson, G.D., Malo, B.A., and Schroder, L.J., 1993, Quality assurance plan for the collection and processing of sediment data by the U.S. Geological Survey, Water Resources Divisions: U.S. Geological Survey OpenFile Report 92-4999, 18p.

Knott, J.M., Sholar, C.J., Matthes, W.J., 1992, Quality assurance guidelines for the analyses of sediment concentration by U.S. Geological Survey Sediment Laboratories: U.S. Geological Survey Open-File Report 92-33.

Novak, C.E., 1985, Preparation of water-resources data reports: U.S. Geological Survey Open-File Report 85-480, 331p.

Porterfield, G., 1972, Computation of fluvial sediment discharge: U.S. Geological Survey Techniques of WaterResources Investigations, book 3, chap. C3, 66p.

U.S. Geological Survey, 1970, Sedimentation and erosion techniques: U.S. Geological Survey Techniques of WaterResources Investigations, book 3, chaps. C1-C2, variously paged.

U.S. Geological Survey, National field manual for the collection of water-quality data: U.S. Geological Survey Techniques of Water-Resources Investigations, book 9, chaps. A1-A9. 


\section{Appendix}

\section{AUTOMATIC SAMPLER FIELD FORM}

ST. \#

DATE SUBMITTED

XECTION2/FULL SIZZE RECORD \#
DATE COLLECTED

XSECTION1/TURB RECORD \# BED-MATERIAL RECORD \#

\begin{tabular}{|c|l|l|l|c|l|l|l|}
\hline $\begin{array}{c}\text { BOTTLE } \\
\#\end{array}$ & DATE & TIME & REMARKS & $\begin{array}{c}\text { BOTTLE } \\
\#\end{array}$ & DATE & TIME & REMARKS \\
\hline 1 & & & & 15 & & & \\
\hline 2 & & & & 16 & & & \\
\hline 3 & & & & 17 & & & \\
\hline 4 & & & & 18 & & & \\
\hline 5 & & & & 19 & & & \\
\hline 6 & & & & 20 & & & \\
\hline 7 & & & & 21 & & & \\
\hline 8 & & & & 22 & & & \\
\hline 9 & & & & 23 & & & \\
\hline 10 & & & & 24 & & & \\
\hline 11 & & & & 25 & & & \\
\hline 12 & & & & 26 & & & \\
\hline 13 & & & & & & & \\
\hline 14 & & & & & & & \\
\hline
\end{tabular}

XSECTION 1/ TURBIDITY SAMPLE:

SAMPLE DATE

LAB \#

REMARKS
Mean TIME

GAGE HT TEMP \# BOTTLES

(

XSECTION 2/ FULL SIZE SAMPLE:

SAMPLE DATE

LAB \#

REMARKS

GAGE HT

Mean TIME

TEMP

TEMP

\# BOTTLES
IF FULL SIZE: ALSO INCLUDE

STREAM WIDTH

MEAN DEPTH

BED MATERIAL: TIME
MEAN VELOCITY

INST. Q.

\# SECTIONS 
Physical Description: Weather: Sky - Clear Partly cloudy Cloudy Precip - Light Medium Heavy Snow Rain Mist WindCalm Light breeze Windy Gusty Est wind speed mph Temp - Very Cold Cool Warm Hot

Water Flowing: YES NO Approx. Depth

Stage of Intake Location:

Stage of actuators locations:

Distance from bed to intake:

Depth of water at intake:

Distance above or below intake from surface of water:

Equipment Functioning: YES NO Maintenance needed:

Was intake line moved? YES NO

Check Samples:

Batt. Voltage

Isco checks taken: YES NO Equipment Blanks taken: YES NO Xsections taken: YES NO

Any conditions that might affect the record:

Comments: 


\section{Appendix (continued)}

\section{₹USGS \\ science for a changing world}

\section{SEDIMENT DATA COLLECTION FIELD NOTES}

XSECTION1/TURB. RECORD \# XSECTION2/TLSIZE RECORD \#

TL BED RECORD \#

Station Number Station Name

Date Turbidity Time

Total Load: Bed Time

Size Time

Check Sample/Xsection Times: CS1 XS1

CS2

XS2 CS3

Sampling Team Sample Purpose (71999) Sample Type Project No.

Sample Medium: Turb TL: Size Bed Xsection 1 Xsection 2

\section{SAMPLES COLLECTED \\ _ Bed \\ _ Suspended Sediment \\ — Turbidity}

Lab Codes (A) Add (D) Delete _ 2187 Gage Ht (00065) Water temp (00010) Air Temp (00020) $\mathrm{pH}(00400)$ Sp Cond (00095) Dis Oxy (00300) DO Sat (00301) Bar Press (00025)
Q. Instant (00061)

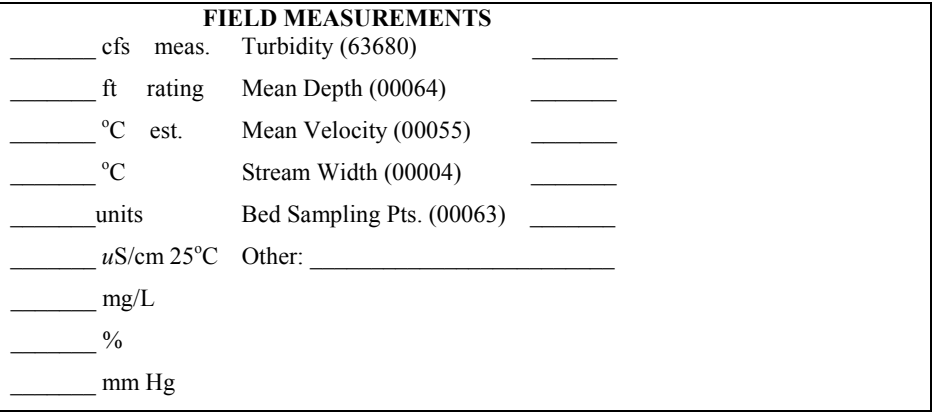

SAMPLING INFORMATION

Sampling Method (82398) Sampler Type (84164): DH-48 (3001) DH-59 (3002) BMH-53 (3023) BMH-60 (3027)

RBM-80 (3029) DH-81 (3044) DH-81 Teflon (3045) DH-95 Teflon (3051) DH-95 Plastic (3052) Other:( )

Nozzle Size: 3/16" 1/4" 5/16" Sample/Compositor/Splitter: Churn 4L

Stream width ft mi Left Bank Right Bank

Samples points (either spacing or actual point sample collected at)

Sampling Location: Wading Cableway Ice Boat Bridge Upstream Downstream side of bridge $\mathrm{ft}$ mi above below gage Sampling Site: Pool Riffle Open Channel Braided Backwater Bottom: Rock Cobble Gravel Sand Silt Concrete Other Sampling Color: Brown Green Blue Gray Clear Other Stream mixing: Excellent Good Fair Poor Stratified Other Weather: Sky - Clear Partly cloudy Cloudy Precip - Light Medium Heavy Snow Rain Mist Wind - Calm Light breeze Windy Gusty Est wind speed mph Temp - Very Cold Cool Warm Hot Comments: 


\section{METER CALIBRATIONS AND LOT NUMBERS}

\begin{tabular}{|c|c|c|c|c|c|c|c|c|}
\hline \multicolumn{4}{|c|}{ pH Meter Make/Model } & \multicolumn{3}{|c|}{$\mathrm{S} / \mathrm{N}$ or $\mathrm{W} / \mathrm{N}$} & \multicolumn{2}{|c|}{ Type: Gel Liquid Otl } \\
\hline \multicolumn{2}{|c|}{ Sample: $\quad$ Filtered } & Unfiltered & \multicolumn{2}{|c|}{ Cone Splitter } & Churn & Single Point at___ $\mathrm{ft}$ deep & \multicolumn{2}{|c|}{ Vertical Ave. of } \\
\hline $\begin{array}{l}\mathrm{pH} \\
\text { Buffer }\end{array}$ & $\begin{array}{l}\text { Buffer } \\
\text { Temp }\end{array}$ & $\begin{array}{l}\mathrm{pH} \text { value } \\
\text { from } \\
\text { table }\end{array}$ & $\begin{array}{l}\text { Initial } \\
\mathrm{pH} \\
\text { value }\end{array}$ & $\begin{array}{l}\text { Adjusted } \\
\text { pH value }\end{array}$ & Slope & Buffer lot number & $\begin{array}{l}\text { Buffer } \\
\text { Expiration } \\
\text { Date }\end{array}$ & Comments \\
\hline \multicolumn{9}{|l|}{$\mathrm{pH} 7$} \\
\hline \multicolumn{9}{|l|}{$\mathrm{pH} 10$} \\
\hline & & & & & & & & \\
\hline & & & & & & & & \\
\hline \multicolumn{9}{|c|}{ Field Readings ______ Use: ___ units REMARK___ Qualifier ___ _ _ _ _ _ _ _ _ } \\
\hline
\end{tabular}

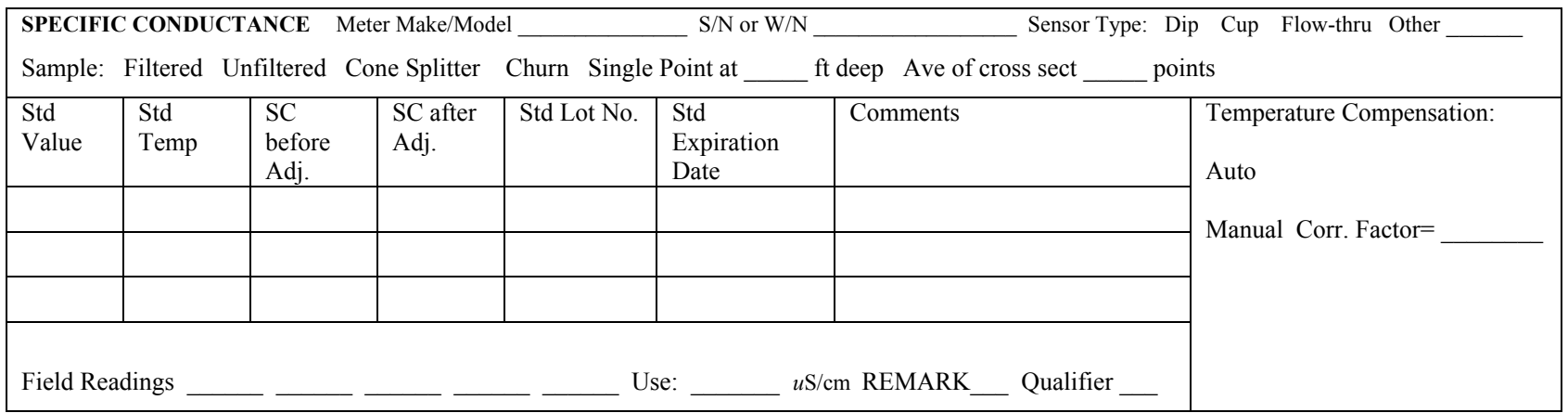

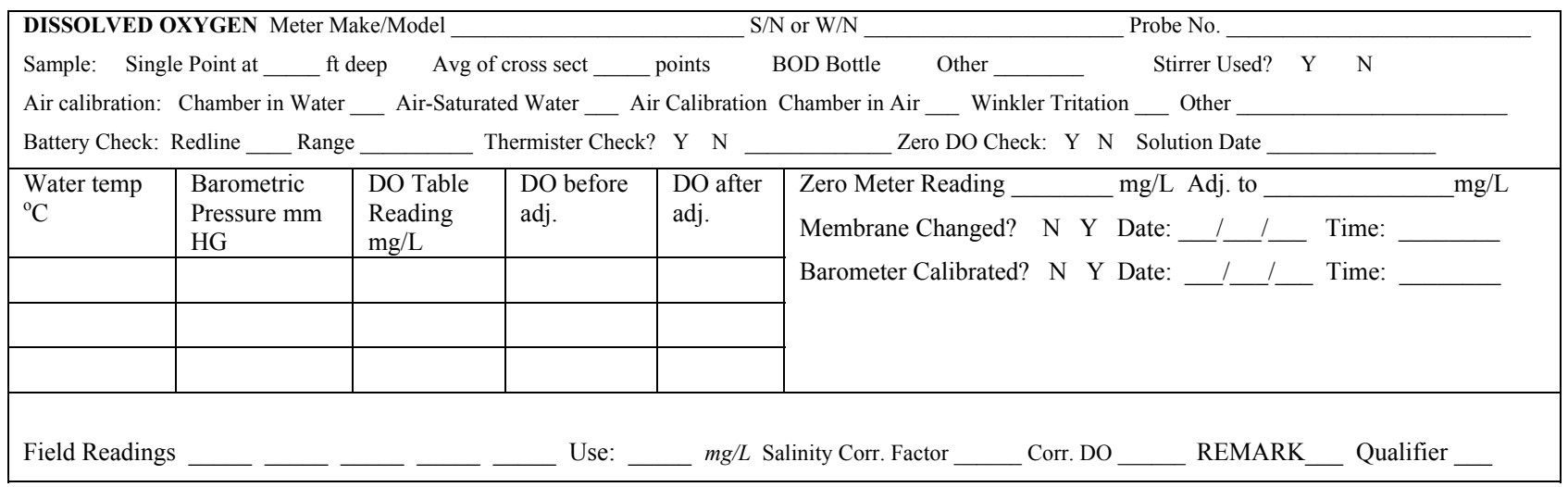

\begin{tabular}{|c|c|c|c|c|c|c|c|c|}
\hline \multicolumn{3}{|c|}{$\frac{\text { TURBIDITY }}{\text { Calibration Criteria: } \pm 2 \text { NTU or } \pm 5 \%}$} & \multicolumn{3}{|c|}{$\begin{array}{l}\text { Calibration Check } \\
\text { Time }\end{array}$} & \multicolumn{3}{|c|}{$\begin{array}{l}\text { Recalibration } \\
\text { Time }\end{array}$} \\
\hline & Date Prepared & $\begin{array}{l}\text { CONC } \\
\text { NTU }\end{array}$ & $\begin{array}{c}\text { TEMP } \\
{ }^{\circ} \mathrm{C}\end{array}$ & READING & $\begin{array}{c}\text { ERROR } \\
\%\end{array}$ & $\begin{array}{c}\text { TEMP } \\
{ }^{\circ} \mathrm{C}\end{array}$ & READING & $\begin{array}{c}\text { ERROR } \\
\%\end{array}$ \\
\hline $\begin{array}{l}\text { Stock Turbidity } \\
\text { Standard }\end{array}$ & & & & & & & & \\
\hline $\begin{array}{l}\text { Zero NTU } \\
\text { Standard (DIW) }\end{array}$ & & & & & & & & \\
\hline Standard 1 & & & & & & & & \\
\hline Comments: & & & & & & & & \\
\hline
\end{tabular}




\section{CROSS SECTION SURVEY INFORMATION}

Method EWI EDI Other__ No. of Verticals

Measurement Location:___ $\mathrm{ft}$ upstream downstream of monitor

Stream Mixing: Excellent Good Fair Poor

Comments

\begin{tabular}{|l|c|c|c|c|c|c|c|c|c|}
\hline STATION & Time & $\begin{array}{c}\text { Ft from left } \\
\text { bank or from } \\
\text { right bank } \\
(00009)\end{array}$ & $\begin{array}{c}\mathrm{TEMP}^{\circ} \mathrm{C} \\
(00010)\end{array}$ & $\begin{array}{c}\mathrm{SC} \\
(00095)\end{array}$ & $\begin{array}{c}\text { DO mg/L } \\
(00300)\end{array}$ & $\begin{array}{c}\mathrm{pH} \\
(00400)\end{array}$ & $\begin{array}{c}\text { Turbidity } \\
(63680)\end{array}$ & DO \% & DO CH \\
\hline
\end{tabular}

\begin{tabular}{|l|l|l|l|l|l|l|l|l|} 
STATION & Time & $(00009)$ & $(00010)$ & $(00095)$ & $(00300)$ & $(00400)$ & $(63680)$ & \\
\hline & & & & & & & & \\
\hline & & & & & & & & \\
\hline
\end{tabular}


Additional Comments:

\begin{tabular}{|c|l|l|l|l|l|l|}
\hline \multirow{3}{*}{$\begin{array}{c}\text { Specific } \\
\text { Conductance }\end{array}$} & Value & Temp & Reading Before & Reading After & Lot \# \\
\cline { 2 - 6 } & & & & & \\
\cline { 2 - 6 } & & & & & \\
\hline
\end{tabular}

\begin{tabular}{|c|l|l|l|l|l|l|l|}
\hline \multirow{2}{*}{$\mathrm{pH}$} & Value & Temp & Theoretical Pt. & Reading Before & Reading After & Lot \# & \\
\cline { 2 - 7 } & 7.0 & & & & & \\
\cline { 2 - 7 } & 10.0 & & & & & \\
\hline
\end{tabular}

\begin{tabular}{|l|l|l|l|l|l|l|l|}
\hline \multirow{3}{*}{ Turbidity } & Value & Date Prepared & Temp & Reading Before & Reading After & Lot \# & \\
\cline { 2 - 7 } & DI Water & & & & & \\
\cline { 2 - 7 } & 123 & & & & & \\
\hline
\end{tabular}

\begin{tabular}{|l|l|l|l|l|l|}
\hline \multirow{2}{*}{ DO } & Temp & Barometric Pressure & DO Table Reading & Reading Before \\
\cline { 2 - 6 } & & & & & \\
\hline
\end{tabular}




\title{
Appendix (continued)
}

\author{
UNITED STATES \\ DEPARTMENT OF THE INTERIOR \\ GEOLOGICAL SURVEY \\ New Mexico Water Science Center
}

SEDIMENT STATION ANALYSIS FOR WATER YEAR 2006

\section{STATION NAME.--08330000 Rio Grande at Albuquerque, NM}

SAMPLING PROGRAM.--Partial-record sampling was collected from May 1969 to September 1969, then daily suspended sediment sampling began in October 1969 to current year. The stream bed is composed of rock, and boulders, with extremely variable amount of sand on top.

EQUIPMENT.--Daily point samples are collected by an Isco pump sampler (Model 3700) generally at 1300 hours on right bank approximately 30 feet upstream of the bridge. Equal-width-increment (EWI) samples are collected to compare the values obtained by the pump sampler to compute cross-sectional coefficients. Samples are collected with a DH-81 hand sampler when wading and with a D-95 sampler when using the bridge.

SEDIMENT SAMPLES.--There were 27 cross-section EWI suspended-sediment samples and 309 daily point samples collected throughout the year. Periods with missing point sample data are Oct $29-$ Nov 3, Dec 30 - Jan 3, Jan 28 - Feb 1, Feb 16 - March 21, April 16 - may 8, Sept 19 - Sept 25, Sept 27 Sept 30. All suspended sediment samples were analyzed for suspended sediment concentration by the New Mexico Water Science Center's Sediment Lab, and all suspended sediment total size samples were analyzed by the Iowa Water Science Center's Sediment Lab. The sediment concentration input file for GCLAS is "08330000.bcard.2006WY".

WATER DISCHARGE RECORD.--Fifteen minute unit-value surface-water discharge was used in this record for analysis and computation of daily suspended sediment discharge. The DCP gave a complete and satisfactory record for the year except for May 4-5 and May 9-10. The ADAPS "B" card data file used in this sediment analysis was modified to add unit discharges for computing sediment loads on days of questionable gage height record. Specifically, the average daily discharge value was added into the file for each unit value of the day in question. The surface-water discharge record for the water year is rated good except estimated daily discharges, which are poor. The file containing the discharge input for GCLAS is "08330000.Q.corrected.2006WY”.

SEDIMENT LOAD COMPUTATIONS.--Computations were made using GCLAS, (Graphical Constituent Analysis System) a windows and Java based interactive program, for analyzing water quality timeseries data, and computing daily loads of sediment or other stream-water constituents. The name of the sediment analysis GCLAS file is "08330000.2006.final.gpf". The sediment load was computed using the linear algorithm in GCLAS.

EXTREMES FOR FOR WATER YEAR 2006.-- SEDIMENT CONCENTRATION: Maximum daily mean, 41,800 mg/L, Aug. 7; minimum daily mean, $67 \mathrm{mg} / \mathrm{L}$, May 9. SEDIMENT LOAD: Maximum daily 163,000 tons, Aug. 7; minimum daily, 94 tons, March 27.

ANALYSIS OF DAILY POINT SAMPLES.-- The following summarizes the various adjustments made to the point sample record based on analysis of the graph of point samples during the water year: 
11-02-2005 Did not use point sample taken at 12:35. The values appear high based on the point sample graph and may be due to the fact that they were collected after a period of missed record.

01-04-2006 Did not use point sample for this day. The values appear high based on the point sample graph and may be due to the fact that they were collected after a period of missed record.

01-22-2006 Did not use pump sample for this day. The volume is much lower than samples around it.

02-02-2006 Did not use point sample for this day. The values appear high based on the point sample graph and may be due to the fact that they were collected after a period of missed record.

04-11-2006 Did not use point sample 13:45 or 14:00. The values appear low compared to the other samples collected that day.

04-12-2006 Did not use pump sample that day. The volume is real low, at least $200 \mathrm{~mL}$ less than the other continuous samples.

05-09-2006 Did not use pump sample that day. The bottle had a slow leak.

09-26-2006 Did not use point sample for this day. The values appear high based on the point sample graph and may be due to the fact that they were collected after a period of missed record.

ANALYSIS OF CROSS SECTION SAMPLES.--The following summarizes the various adjustments made to the cross section sample record based on analysis of the graph of point samples during the water year.

10-05-2005 Did not use cross section sample. After reviewing the samples surrounding it, it was assumed that all the sediment was not used to accurately calculate the total concentration.

CROSS-SECTION COEFFICIENTS.--The following summarizes the coefficients used throughout the water year. The coefficients at this site can vary according to flow. For flows less than $550 \mathrm{cfs}$, a 1.0 coefficient was used and flows above $725 \mathrm{cfs}$, a 1.5 coefficient was used. A coefficient was prorated between flows of 550 and 725 .

ESTIMATED CONCENTRATION AND LOADS.--When there are no actual samples, or an inadequate number of samples are available, to define a daily sediment transport curve, estimated instantaneous sediment values were made using the reference curve graph in GCLAS. Daily estimated point samples were made for the following day:

Sept 30 .

REMARKS.--The sediment records are fair.

Work by: Jessica A. Stiles 08-08-2007

Checked by: Jeb E. Brown 08-10-2007

Reviewed by: Mike Roark 08-30-2007 